\title{
Assisted reproductive techniques in Latin America: The Latin American Registry, 2014
}

\author{
Fernando Zegers-Hochschild ${ }^{1,2,3}$, Juan Enrique Schwarze ${ }^{3,4}$, Javier A. Crosby ${ }^{1,3}$, Carolina Musri ${ }^{1,3}$, Maria Teresa Urbina ${ }^{3,5}$ \\ ${ }^{1}$ Reproductive Medicine Unit - Las Condes Clinic, Chile \\ ${ }^{2}$ Ethics and Public Policies Program in Human Reproduction, University Diego Portales, Chile \\ 3 Latin American Network of Assisted Reproduction (REDLARA), Uruguay \\ ${ }^{4}$ Reproductive Medicine Unit - Monteblanco Clinic, Chile \\ ${ }^{5}$ Unifertes, Venezuela
}

Key message: There has been a systematic effort to decrease the proportion of high order multiple deliveries. Latin America is moving in the right direction and we should pursue in educating both clinicians and patients towards reducing further the number of embryos transferred, especially in good prognosis cases.

\begin{abstract}
Multinational data on assisted reproduction techniques undertaken in 2014 were collected from 159 institutions in 15 countries in Latin America. Treatments included IVF/ ICSI, FET, OD, PGD and fertility preservation (FP). $41.34 \%$ of IVF/ICSI cycles were performed in women aged 35 to 39 years and $23.35 \%$ in women aged 40 and older. After removing cases with total freezing, delivery rate per oocyte retrieval was $25.05 \%$ for ICSI and $27.41 \%$ for IVF. Multiple births included $20.78 \%$ twins and $0.92 \%$ triplets and over. In OD, twins reached $28.93 \%$ and triplets $1.07 \%$. Preterm deliveries reached $16.4 \%$ in singletons, $55.02 \%$ in twins and $76 \%$ in triplets. Perinatal mortality in 18,162 births was 23 per 1000 in singletons, 35 per 1000 in twins, and 36 per 1000 in high-order multiples. Elective single embryo transfer (eSET) represented only $2.63 \%$ of fresh transfers, with a delivery rate of $32.15 \%$ per transfer. Elective double embryo transfer (eDET) represented $23.74 \%$ of transfers, with a delivery rate of $41.03 \%$ per transfer. Among babies born during this period $11,373(62.6 \%)$ were singletons; $6,398(35.2 \%)$ twins, and $391(2.2 \%)$, triplets and more. Given the effect of multiple births on prematurity, morbidity and perinatal mortality, reinforcing the existing trend of reducing the number of embryos transferred is mandatory
\end{abstract}

Keywords: assisted reproductive technology, epidemiology, in vitro fertilization, Intracytoplasmic Sperm Injections, Latin America, pregnancy outcomes, registry

\section{INTRODUCTION}

The Latin American Registry of Assisted Reproduction (RLA) was established in 1990 as the first multinational and regional registry of assisted reproductive technology (ART). Yearly, a report is provided containing outcome of ART procedures performed by 159 institutions in 15 countries from Mexico in the north to Chile in the south. All institutions reporting to the registry need to be certified by an independent body before their data are accepted. The accreditation team consists of a clinician and a biologist from a different country who follows a pre-established protocol (www.redlara.com). The software developed for data registration and centralized reporting system has received several modifications over time. Since 2010, individualised case-by-case data are obtained, thus establishing the first cycle based multinational registry.

The main objectives of RLA are: a) Disseminate information on ART procedures performed in Latin America; which serves as an external quality control to be used by institutions performing ART in the region and for other regions of the world; b) Monitor outcomes, as well as trends in safety and efficacy. Monitoring these two variables contribute to developing better health interventions and developing appropriate public policies; and c) Empower infertile couples in their capacity to evaluate risks and benefits when requesting ART treatments, and developing a robust database for epidemiological studies. It is often very difficult for an infertile and sometimes vulnerable person, to understand the risks and benefits involved in the treatment offered. Access to an objective and external database is often well received by infertile persons when deciding if treatment should be undertaken, such as how many embryos to transfer.

This report corresponds to the $26^{\text {th }}$ edition of RLA. Previous reports, from 1990 to 1998, are available as printed copies; from 1999 to 2009 as PDF files, which can be downloaded from the web page www.redlara.com. Today, reports are published simultaneously in RBM Online, and in the JBRA Assisted Reproduction, the official journal of REDLARA.

In this report we are communicating information on access, effectiveness, and perinatal outcomes of ART treatment initiated between $1^{\text {st }}$ January 2014 and $31^{\text {st }}$ December 2014, and babies born up to September 2015.

\section{MATERIAL AND METHODS}

Data on ART were collected from 159 centres in fifteen countries in Latin America (Supplementary Table I), covering initiated autologous cycles of in vitro fertilisation (IVF), intra-cytoplasmic sperm injection (ICSI), frozen embryo transfer (FET), fresh oocyte donation (Fresh OD), frozen oocyte donation (FET OD), pre implantation genetic diagnosis and screening, registered together as PGD, and fertility preservation (FP). Data on intrauterine insemination using husband (IUI-H) and donor (IUI-D) semen is also provided.

This report includes treatments started between $1^{\text {st }}$ January 2014 and $31^{\text {st }}$ December 2014. Data on pregnancy and neonatal outcomes are obtained from follow-up of the cohort treated during this time period. As part of the accreditation programme, all participating institutions agree to have their data registered and published by the Latin American Registry of ART. Therefore, no other consent form is requested for the scientific disclosure of this data.

The method of collecting data in 2014 is similar to that used in the previous three years, making results comparable. Briefly, each institution enters their data directly in an online RLA web-based system, with builtin algorithms for internal consistency. Any error or discrepancy, not identified by the software, is discussed and clarified by RLA's central office. Given that the RLA is a voluntary multinational registry, centres are not obliged to upload each case immediately when the cycle is initiated. Therefore, some cases are sent to the RLA upon patient recruitment while others are included retrospectively. This can indeed affect overall results because there could be a selection of predominantly those initiated cycles that advanced towards aspiration. 
Definitions used refer to the glossary developed by the International Committee for Monitoring Assisted Reproductive Technologies (ICMART) and the World Health Organization (WHO) (Zegers-Hochschild et al., 2009). Preimplantation genetic diagnosis and screening are registered together as PGD.

When appropriate, a chi-squared test to analyse independence of categorical variables is used. A $p$-value less than 0.05 was considered statistically significant. Relative risks are presented with the corresponding 95\% confidence interval.

\section{RESULTS}

\section{Participation}

One hundred and fifty-nine centres in 15 countries reported ART procedures performed during 2014. The majority of centres were located in Brazil ( $n=54$ clinics), Mexico ( $n=31$ clinics), and Argentina ( $n=24$ clinics) (Table 1$)$.

\section{Size of participating institutions}

A total of 65,534 initiated cycles were reported, corresponding to IVF/ICSI, FET, Fresh OD, FET OD and fertility preservation (FP) cycles. The mean number of initiated cycles by institution was 379 (SD402). Of the reporting centres, $17 \%$ performed $\leq 100$ cycles; $36 \%$ between 100 and 250 cycles; $24 \%$ between 251 and 500 cycles; $15 \%$ between 500 and 1,000 cycles; and $8 \% \geq 1,000$ cycles.

\section{Number of treatment cycles per technique and availability}

Out of 65,534 cycles reported during 2014, 38,086 corresponded to initiated IVF/ICSI cycles $(1,592$ more than in $2013,4.4 \%) ; 13,545$ initiated FET $(2,633$ more than in $2013 ; 24.1 \%) ; 11,194$ initiated fresh OD and
FET OD cycles $(2,760$ more than in $2013 ; 32.7 \%)$ and 2,709 initiated FP, (1093 cycles more than 2013; 67.6\%) (Zegers-Hochschild et al., 2016;b).

Of the 38,086 IVF/ICSI cycles, at least one metaphase-2 oocyte was recovered in 35,023 aspirations $(92.00 \%$ of cases). The preferred method for insemination was ICSI $(85.47 \%)$ and at least one embryo was transferred in 25,704 cases. The three main reasons for no embryo transfer were: 6,457 cases of total embryo cryopreservation, 1,391 cases of abnormal in vitro embryo development, and 1,218 cases of total fertilization failure. There were 253 cases where no normal embryos were obtained after PGD as well as other gamete/embryo abnormalities.

Availability of assisted reproductive techniques is still very low in Latin America; in 2014 it reached 116 initiated cycles per million people, ranging from 6 cycles per million in Dominican Republic to 348.8 cycles per million in Argentina (Table 1).

\section{Outcome of pregnancies and deliveries}

Table 2 shows the clinical pregnancy rate (CPR) and delivery rate (DR) per oocyte pick-up (OPU) in IVF/ICSI cycles. Both CPR and DR per OPU were higher in IVF cycles than in ICSI cycles $(27.59 \%$ and $25.16 \%, p<0.001$; $22.76 \%$, and $20.40 \%, p<0.001$, respectively). The CPR and DR per OPU increased considerably when cycles with total embryo cryopreservation were subtracted, reaching a DR/OPU of $27.4 \%$ for ICSI and $25.05 \%$ for IVF.

In fresh cycles, both CPR and DR per ET were higher in OD than in autologous cycles reaching $50.87 \%$ and $42.59 \%$, respectively, in OD cycles (Table 3 ).

Also in FET cycles, both CPR and DR were higher when embryos were obtained from donated oocytes compared with autologous oocytes $(37.92 \%$ versus $34.92 \% ; 30.93 \%$, versus $28.47 \%$ ) (Table 3 ).

\begin{tabular}{|c|c|c|c|c|c|c|c|c|c|c|}
\hline \multirow{2}{*}{ Country } & \multirow{2}{*}{$\begin{array}{c}\text { Number } \\
\text { of } \\
\text { clinics }\end{array}$} & \multicolumn{7}{|c|}{ Assisted reproductive techniques } & \multirow{2}{*}{ Total } & \multirow{2}{*}{$\begin{array}{c}\text { Availability } \\
\text { cycles/ } \\
\text { million }^{1}\end{array}$} \\
\hline & & IVF/ICSIa & IVFb & ICSI $^{b}$ & FET ${ }^{\mathbf{a}}$ & $\begin{array}{c}\text { Fresh } \\
\text { OD }^{\mathrm{a}}\end{array}$ & $O D(F E T)^{a}$ & $\mathbf{F P a}$ & & \\
\hline Argentina & 24 & 9,083 & 954 & 7,215 & 2,903 & 1,826 & 663 & 505 & 14,980 & 348.8 \\
\hline Bolivia & 3 & 430 & 221 & 195 & 41 & 86 & 13 & 6 & 576 & 55.7 \\
\hline Brazil & 54 & 16,474 & 878 & 14,473 & 6,877 & 1,728 & 943 & 1,247 & 27,269 & 133.4 \\
\hline Chile & 9 & 2,111 & 124 & 1,792 & 881 & 461 & 188 & 150 & 3,791 & 211.0 \\
\hline Colombia & 11 & 1,196 & 357 & 753 & 289 & 246 & 102 & 35 & 1,868 & 38.5 \\
\hline Ecuador & 6 & 663 & 181 & 398 & 200 & 228 & 59 & 168 & 1,318 & 81.6 \\
\hline Guatemala & 1 & 103 & 60 & 42 & 33 & 17 & 4 & 4 & 161 & 10.0 \\
\hline Mexico & 31 & 4,862 & 1,390 & 3,205 & 1,499 & 2,016 & 744 & 100 & 9,221 & 76.6 \\
\hline Nicaragua & 1 & 98 & 17 & 68 & 0 & 14 & 0 & 0 & 112 & 18.0 \\
\hline Panama & 1 & 239 & 0 & 196 & 65 & 46 & 25 & 14 & 389 & 97.7 \\
\hline Paraguay & 1 & 75 & 37 & 25 & 18 & 17 & 4 & 0 & 114 & 16.3 \\
\hline Peru & 7 & 1,286 & 443 & 755 & 445 & 742 & 478 & 433 & 3,384 & 108.1 \\
\hline Dominican $R$. & 1 & 30 & 11 & 19 & 5 & 32 & 0 & 0 & 67 & 6.4 \\
\hline Uruguay & 2 & 317 & 30 & 238 & 78 & 84 & 22 & 13 & 514 & 150.3 \\
\hline Venezuela & 7 & 1,119 & 385 & 561 & 211 & 286 & 120 & 34 & 1,770 & 58.2 \\
\hline Total & 159 & 38,086 & 5,088 & 29,935 & 13,545 & 7,829 & 3,365 & 2,709 & 65,534 & 116 \\
\hline
\end{tabular}

a Initiated cycles.

b Oocyte pick-ups with $\geq 1$ mature oocyte.

1 Number of cycles in the country divided by its population in 2014 (World Population Data Sheet, World Bank). 
Table 2. Clinical pregnancy rate and delivery rate in IVF/ICSI cycles in 2014.

\begin{tabular}{|l|c|c|c|c|c|}
\hline ART procedure & $\begin{array}{c}\text { Oocyte pick up } \\
\text { (OPU) }\end{array}$ & $\begin{array}{c}\text { Clinical preg- } \\
\text { nancy rate per } \\
\text { OPU }\end{array}$ & $\begin{array}{c}\text { Clinical preg- } \\
\text { nancy rate per } \\
\text { OPU(*) }\end{array}$ & $\begin{array}{c}\text { Delivery rate } \\
\text { per OPU }\end{array}$ & $\begin{array}{c}\text { Delivery rate } \\
\text { per OPU(*) }\end{array}$ \\
\hline$I C S I$ & 29,935 & $25.16 \%$ & $30.89 \%$ & $20.40 \%$ & $25.05 \%$ \\
\hline$I V F$ & 5,088 & $27.59 \%$ & $33.24 \%$ & $22.76 \%$ & $27.41 \%$ \\
\hline$P$-value & & 0.001 & 0.009 & $<0.001$ & 0.002 \\
\hline
\end{tabular}

$\mathrm{OPU}=$ oocyte pick up with at least one mature oocyte

(*) Excluding cycles with total embryo cryopreservation.

Table 3. Clinical pregnancy rate and delivery rate in IVF/ICSI cycles in 2014.

\begin{tabular}{|l|c|c|c|}
\hline ART procedure & Embryo transfer (ET) & $\begin{array}{c}\text { Clinical pregnancy rate } \\
\text { per ET }\end{array}$ & Delivery rate per ET \\
\hline Fresh $O D$ & 6,161 & $50.87 \%$ & $42.59 \%$ \\
\hline FET & 13,114 & $34.92 \%$ & $28.47 \%$ \\
\hline$O D(F E T)$ & 3,262 & $37.92 \%$ & $30.93 \%$ \\
\hline
\end{tabular}

Not consistent with Table 1.

$\mathrm{OD}=$ oocyte donation.

FET $=$ frozen/thawed embryo transfer.

\section{Age distribution}

The mean age of women undergoing IVF/ICSI was 36.4 (SD4.5). The majority of cycles were performed in women aged 35 to 39 years $(41.34 \%)$, followed by women aged 40 and older (23.35\%); which means that $64.7 \%$ of women using autologous ART are $\geq 35$ years. The mean age of women undergoing fresh OD was 41.3 (SD5.1); and the majority of cycles were performed in women aged 40 years and older (67.3\%). As expected the DR per embryo transfer decreased with advancing age in the case of IVF/ ICSI, but not in fresh OD (Figure 1).

\section{births}

Number of embryos transferred and multiple

Table 4 summarises the number of embryos transferred after IVF/ICSI, with a mean of 2.06 embryos (range 1-6). There were 4,691 single embryo transfers (SET), which correspond to $18.25 \%$ of all transfers (16.9\% in 2013). Of these, only 675 were elective SET, representing a $2.63 \%$ of ET. There were 15,435 double embryo transfers (DET), which correspond to $60.05 \%$ of ET $(57.2 \%$ in 2013). Of these, 6,103 were elective DET, a $23.74 \%$ of ET.

In women $\leq 34$ years, the mean number of embryos transferred remained almost unchanged, at 2.01 embryos (range 1 to 5 ). In this age group $13.77 \%$ were SET, $72.01 \%$ DET, and in $13.44 \%$ TET (three embryos transferred); while more than TET occurred in $0.78 \%$ of transfers. In this age category the proportion of eSET accounted for $3.82 \%$ of ET, and eDET for $34.16 \%$ of ET. Overall the CPR per ET reached $35.08 \%$, while the DR per ET reached $28.53 \%$. Of the 7,334 deliveries registered, $78.31 \%$ were singletons, $20.78 \%$ were twins, and $0.92 \%$ were triplets and higher.

Table 5 summarises the number of embryo transfers in fresh OD, where the mean number of embryos transferred reached 2.17 (range 1-6). There were 499 SET, which correspond to $8.1 \%$ of ET $(7.02 \%$ in 2013$)$. Of these, 366 were eSET representing a $5.94 \%$ of ET. There were 4,281 DET, which correspond to $69.49 \%$ of ET $(65.82 \%$ in 2013$)$. Of these, 3,131 were eDET; a $50.82 \%$ of ET.

Overall the CPR per ET reached $50.87 \%$, while the DR per ET reached $42.59 \%$. Of the 2,624 deliveries registered, $70.01 \%$ were singletons, $28.93 \%$ were twins, and $1.07 \%$ were triplets and higher.

Table 6 summarises the number of embryos transferred in FET, where the mean number of embryos transferred reached 2.06 (range 1-5). There were 2,917 SET, which correspond to $22.24 \%$ of ET ( $26.52 \%$ in 2013 ). There were 8,096 DET, which correspond to $61.74 \%$ of ET $(61.84 \%$ in 2013). Overall the CPR per ET reached $34.92 \%$, while the DR per ET reached $28.47 \%$. Of the 3,734 deliveries registered, $80.34 \%$ were singletons, $18.93 \%$ were twins, and $0.72 \%$ were triplets and higher.

Table 7 summarises the number of embryos transfers in FET OD, where the mean number of embryos transferred reached 1.95 (range 1-6). There were 670 SET, which correspond to $20.54 \%$ of ET (31.20\% in 2013). There were 1,930 DET, which correspond to $59.17 \%$ of ET $(37.69 \%$ in 2013). Overall the CPR per ET reached $37.92 \%$, while the DR per ET reached $30.93 \%$. Of the 1,009 deliveries registered, $78.59 \%$ were singletons, $20.71 \%$ were twins, and $0.69 \%$ were triplets and higher

Outcome according to the number of ET and stage of development at transfer

In women $\leq 34$ years undergoing IVF/ICSI, the mean number of cleavage-stage embryos transferred was 2.05 (range 1-5) and 1.91 (range 1-4) when blastocysts were transferred. In fresh $O D$, the mean number of cleavagestage embryos transferred was 2.32 (range 1-5) and 2.00 (range 1-6) when blastocysts were transferred.

We also analyzed DR/ET according to the number of embryos transferred and developmental-stage of embryo at transfer. In IVF/ICSI as well as in fresh OD, the transfer of blastocysts was always associated with an increase in the DR/ET compared to cleaving stage embryos transfers, irrespective of the number of embryos transferred. In the case of IVF/ICSI, the DR/ET reached $35.80 \%$ when blastocysts were transferred, and $26.02 \%$ when cleavagestage embryos were transferred (RR 1.37, CI95\% 1.32$1.43 ; p<0.0001)$. In the case of fresh OD, the DR/ET was $51.14 \%$ when blastocysts where transferred, and $28.47 \%$ when cleavage-stage embryos were transferred (RR 1.80, CI95\% 1.72-1.88; $p<0.0001$ ).

When including all transfers, irrespective of the stage of development at transfer, DR/ET in IVF/ICSI, was $15.16 \%$ for one embryo, $31.88 \%$, for two embryos and $30.51 \%$ when three-or-more embryos were transferred (one vs. two $p<0.0001$; two vs. three-and-more $p=0.0591$ ). Furthermore, elective single embryo transfer was associated to $32.15 \%$ DR/ET; while elective double embryo transfer was associated to $41.03 \%$ DR/ET. 


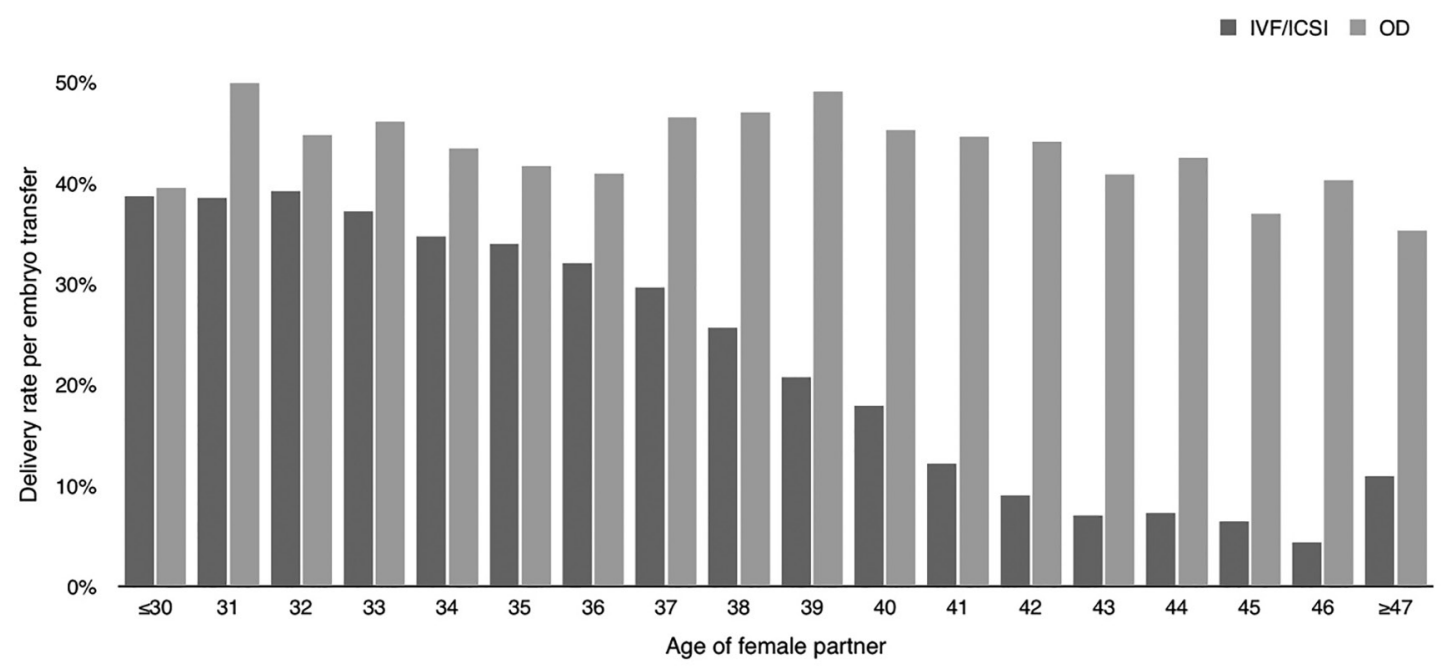

Figure 1. Comparison of delivery rate per embryo transfer IVF/ICSI and fresh OD cycles RLA 2014.

Table 4. Clinical pregnancy rate, delivery rate and gestational order according to the number of embryos transferred in IVF/ICSI cycles in 2014.

\begin{tabular}{|c|c|c|c|c|c|c|c|c|}
\hline \multirow{2}{*}{$\begin{array}{l}\text { Number of } \\
\text { transferred } \\
\text { embryos }\end{array}$} & \multicolumn{2}{|c|}{ Total ET } & \multirow[b]{2}{*}{$C P R / E T$} & \multicolumn{5}{|c|}{ Deliveries } \\
\hline & Number & $\%$ & & $\begin{array}{c}\text { Total } \\
\text { (number) }\end{array}$ & DR/ET & $\begin{array}{c}\text { Singleton } \\
(\%)\end{array}$ & $\begin{array}{l}\text { Twin } \\
(\%)\end{array}$ & $\begin{array}{c}\geq \text { Triplets } \\
(\%)\end{array}$ \\
\hline 1 & 4,691 & 18.25 & $20.34 \%$ & 711 & $15.157 \%$ & 98.03 & 1.97 & \\
\hline 2 & 15,435 & 60.05 & $38.79 \%$ & 4,921 & $032 \%$ & 76.06 & 23.41 & 0.53 \\
\hline 3 & 4,989 & 19.41 & $37.54 \%$ & 1,549 & $031 \%$ & 76.31 & 21.11 & 2.58 \\
\hline$\geq 4$ & 589 & 2.29 & $33.28 \%$ & 153 & $026 \%$ & 78.13 & 20.78 & 0.92 \\
\hline Total & 25,704 & 199 & $35.08 \%$ & 7,334 & ,533\% & 78.31 & 20.78 & 0.92 \\
\hline
\end{tabular}

$\mathrm{ET}=$ embryo transfers.

$\mathrm{CPR}=$ clinical pregnancy rate.

$\mathrm{DR}=$ delivery rate.

\begin{tabular}{|c|c|c|c|c|c|c|c|c|}
\hline \multirow{2}{*}{$\begin{array}{l}\text { Number of } \\
\text { transferred } \\
\text { embryos }\end{array}$} & \multicolumn{2}{|c|}{ Total ET } & \multirow[b]{2}{*}{ CPR/ET } & \multicolumn{5}{|c|}{ Deliveries } \\
\hline & number & $\%$ & & $\begin{array}{c}\text { Total } \\
\text { (number) }\end{array}$ & DR/ET & $\begin{array}{c}\text { Singleton } \\
(\%)\end{array}$ & $\begin{array}{l}\text { Twin } \\
(\%)\end{array}$ & $\begin{array}{c}\geq \\
\text { Triplets } \\
\text { (\%) }\end{array}$ \\
\hline 1 & 499 & 8.10 & 43.89 & 172 & 34.47 & 97.09 & 2.91 & \\
\hline 2 & 4281 & 69.49 & 51.53 & 1852 & 43.26 & 68.03 & 31.32 & 0.65 \\
\hline 3 & 1246 & 20.22 & 51.69 & 548 & 43.98 & 67.52 & 29.56 & 2.92 \\
\hline$\geq 4$ & 135 & 2.19 & 48.15 & 52 & 38.52 & 76.92 & 23.08 & \\
\hline Total & 6161 & 199 & 50.87 & 2624 & 42.59 & 70.01 & 28.93 & 1.07 \\
\hline
\end{tabular}

$\mathrm{ET}=$ embryo transfers.

$\mathrm{CPR}=$ clinical pregnancy rate.

$\mathrm{DR}=$ delivery rate.

In OD cycles, the DR/ET was $34.47 \%$ in SET, compared with $43.26 \%$ and $43.45 \%$, when two or three-or-more embryos were transferred, respectively (one vs. two $p=0.0002$; two vs. three-and-more $p=0.9014$ ).

We compared the DR/ET in oocyte recipients with that of women $\leq 34$ years old treated with IVF/ICSI (Figure 2).
The DR/ET after the transfer of one cleaving-stage embryo in fresh OD was not significantly different from the DR/ ET after IVF/ICSI in women $\leq 34$ (RR $0.80,95 \%$ CI $0.56-$ 1.14). The DR/ET after the transfer of two cleaving-stage embryos was a slightly lower in fresh OD than after IVF/ICSI in women $\leq 34$ ( RR 0.92, CI95\% 0.86-0.99; $p=0.0339$ ). 
Table 6. Clinical pregnancy rate, delivery rate and gestational order according to the number of embryos transferred in FET in 2014.

\begin{tabular}{|c|c|c|c|c|c|c|c|c|}
\hline \multirow{2}{*}{$\begin{array}{l}\text { Number of } \\
\text { transferred } \\
\text { embryos }\end{array}$} & \multicolumn{2}{|c|}{ Total ET } & \multirow[b]{2}{*}{ CPR/ET } & \multicolumn{5}{|c|}{ Deliveries } \\
\hline & number & $\%$ & & $\begin{array}{c}\text { Total } \\
\text { (number) }\end{array}$ & DR/ET & $\begin{array}{c}\text { Singleton } \\
(\%)\end{array}$ & $\begin{array}{l}\text { Twin } \\
(\%)\end{array}$ & $\begin{array}{c}\geq \text { Triplets } \\
(\%)\end{array}$ \\
\hline 1 & 2917 & 22.24 & 27.36 & 650 & 22.28 & 98.61 & 1.39 & 0.00 \\
\hline 2 & 8096 & 61.74 & 38.33 & 2539 & 31.36 & 77.31 & 22.25 & 0.43 \\
\hline 3 & 1949 & 14.86 & 32.38 & 508 & 26.06 & 74.21 & 23.23 & 2.56 \\
\hline$\geq 4$ & 152 & 1.16 & 30.92 & 37 & 24.34 & 52.63 & 39.47 & 7.89 \\
\hline Total & 13114 & 100.0 & 34.92 & 3734 & 28.47 & 80.34 & 18.93 & 0.72 \\
\hline
\end{tabular}

$\mathrm{ET}=$ embryo transfers.

$\mathrm{CPR}=$ clinical pregnancy rate.

$\mathrm{DR}=$ delivery rate.

\begin{tabular}{|c|c|c|c|c|c|c|c|c|}
\hline \multirow{2}{*}{$\begin{array}{l}\text { Number of } \\
\text { transferred } \\
\text { embryos }\end{array}$} & \multicolumn{2}{|c|}{ Total ET } & \multirow[b]{2}{*}{$C P R / E T$} & \multicolumn{5}{|c|}{ Deliveries } \\
\hline & Number & $\%$ & & $\begin{array}{c}\text { Total } \\
\text { (number) }\end{array}$ & DR/ET & $\begin{array}{c}\text { Singleton } \\
(\%)\end{array}$ & $\begin{array}{l}\text { Twin } \\
(\%)\end{array}$ & $\begin{array}{c}\geq \text { Triplets } \\
(\%)\end{array}$ \\
\hline 1 & 670 & 20.54 & 33.43 & 179 & 26.72 & 96.65 & 3.35 & 0.00 \\
\hline 2 & 1930 & 59.17 & 39.69 & 623 & 32.28 & 76.08 & 23.43 & 0.48 \\
\hline 3 & 608 & 18.64 & 37.50 & 192 & 31.58 & 71.88 & 27.08 & 1.04 \\
\hline$\geq 4$ & 54 & 1.66 & 35.19 & 15 & 27.78 & 53.33 & 33.33 & 13.33 \\
\hline Total & 3262 & 100.00 & 37.92 & 1009 & 30.93 & 78.59 & 20.71 & 0.69 \\
\hline
\end{tabular}

$\mathrm{ET}=$ embryo transfers.

$\mathrm{CPR}=$ clinical pregnancy rate.

$\mathrm{DR}=$ delivery rate.

The DR/ET after the transfer of one blastocyst in fresh OD was significantly higher than the DR/ET after IVF/ICSI in women $\leq 34$ (RR 1.42, CI95\% 1.18-1.70; $p=0.0002$ ). Furthermore, when two blastocysts were transferred, the $D R / E T$ in fresh OD was also significantly higher than the DR/ET after IVF/ICSI in women $\leq 34$ (RR $1.13,95 \%$ CI $1.06-1.20 ; p<0.0001)$.

\section{Perinatal outcome and complications}

Table 8 summarises perinatal mortality. Data were available from 18,162 births. The perinatal mortality increased from 23 per 1,000 births in 11,373 singletons, to 35 per 1000 in 6,398 twins and 36 per 1000 in 391 triplets-and-higher. Overall, $37.38 \%$ of new-borns were multiple. In the case of fresh OD, this proportion increased to $46.58 \%$; while in the case of IVF/ICSI in women younger than 35 , the proportion of multiple babies reached $40.92 \%$ of the 4,506 new-borns.

Gestational age at delivery was reported in 12,110 deliveries (82.34\% of deliveries). The overall risk of preterm birth (gestational weeks 20-36), increased from $16.40 \%$ in singletons, to $55.02 \%$ in twins, and $76.00 \%$ in triplets and higher. Furthermore, the risk of very preterm birth (gestational weeks 20-27) increased from nil in singleton, to $2.16 \%$ in twins and to $4.80 \%$ in triplets and higher.

During 2014, 142 cases of severe OHSS requiring hospitalization or major medical interventions were reported, together with 45 cases of haemorrhage, and 20 cases of infection presumably associated with ovarian puncture. It is likely that these conditions are underreported and only the most severe cases are reported.

\section{PGD/PGS}

The RLA registers PGD and PGS together. 81 centres from 12 countries reported these procedures in 1,811 fresh cycles and 308 using cryopreserved embryo; resulting in 363 fresh embryo transfers and 261 FET. In fresh ET, a total of 117 clinical pregnancies were registered $(32.23 \%$ per ET), and 85 deliveries ( $23.42 \%$ per ET). Corresponding figures for FET were 100 pregnancies ( $38.31 \%$ per ET) and 95 deliveries ( $36.40 \%$ per ET).

The DR per initiated cycle in fresh cycles was strongly associated with the age of the female partner. It reached $7.42 \%$ in women $\leq 34$ years $(31 / 418) ; 5.15 \%$ in women $35-39$ years $(37 / 719) ; 2.95 \%$ in women $40-42$ years $(14 / 475)$; and $1.51 \%$ in women $\geq 43$ years $(3 / 199)$. No ET due to absence of normal embryos also increased with the age of the woman: $13.16 \%$ (55 cases) in women $\leq 34$ year, $19.47 \%$ (140 cases) in women $35-39$ years; $31.16 \%$ (148 cases) in women $40-42$ years; and $42.71 \%$ (85 cases) in women $\geq 43$ years. Finally, DR per ET reached $27.19 \%$ (31/114), 26.81\% (37/138), 16,87\% (14/83), and $10.71 \%$ $(3 / 28)$, respectively. Thus, the transfer of euploid blastocysts generates similar outcome in women up to the age of 39 years. After that, other factors might be responsible for a drop in the DR/ET irrespective of the apparent chromosomal indemnity of embryos after PGD/PGS.

\section{Fertility preservation (FP)}

A total of 2,709 initiated cycles for FP were reported in 2014. The mean age of women was 36 years, range 17 to 51 years. In 35 cases no oocytes were cryopreserved. The mean number of oocytes cryopreserved was 7.0, range 1 to 


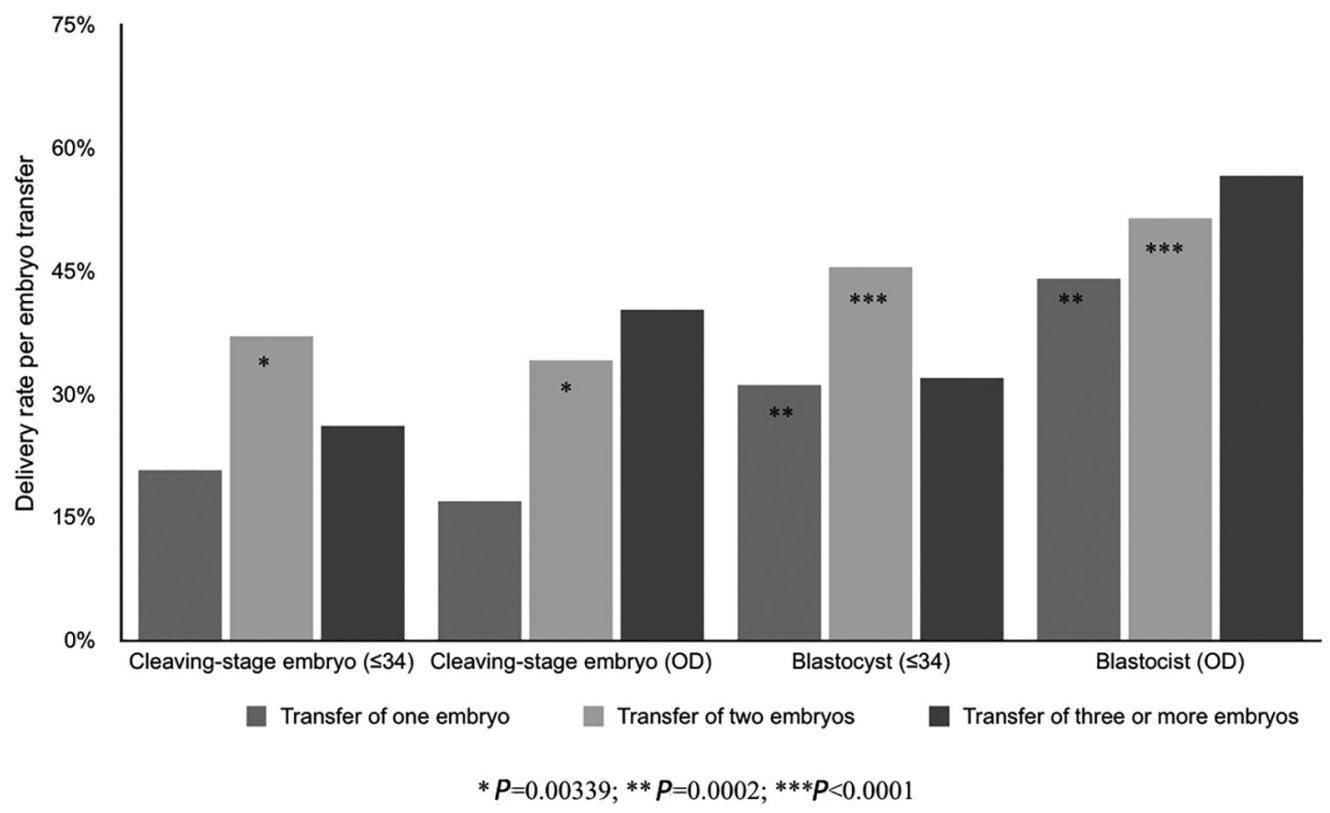

Figure 2. DR per ET according to the number of embryos transferred and developmental stage of embryo(s) in women $\leq 34$ years undergoing IVF/ICSI and women undergoing fresh OD, RLA 2014.

Table 8. Perinatal mortality according to gestational order in 2014.

\begin{tabular}{|l|c|c|c|c|c|c|c|c|c|}
\hline \multirow{2}{*}{ ART procedure } & \multicolumn{3}{|c|}{ Singleton } & \multicolumn{3}{c|}{ Twin } & \multicolumn{3}{c|}{$\geq$ Triplets } \\
\cline { 2 - 11 } & LB & SB & ND & LB & SB & ND & LB & SB & ND \\
\hline IVF/ICSI/other & 5,561 & 136 & 46 & 2886 & 106 & 56 & 193 & 6 & 4 \\
\hline FET & 2977 & 14 & 9 & 1397 & 9 & 8 & 83 & 0 & 0 \\
\hline Fresh OD & 1792 & 33 & 12 & 1473 & 30 & 15 & 80 & 3 & 1 \\
\hline OD (FET) & 780 & 5 & 8 & 415 & 1 & 2 & 21 & 0 & 0 \\
\hline Total & 11,110 & 188 & 75 & 6,171 & 146 & 81 & 377 & 9 & 5 \\
\hline Perinatal mortality (*) & \multicolumn{3}{|c|}{23} & & 35 & & & 36 \\
\hline
\end{tabular}

$\left(^{*}\right)$ proportion of still birth plus early neonatal death per 1,000 newborns.

LB = live birth; $\mathrm{SB}=$ still birth; ND = early neonatal death.

39. In cases where the indication for FP was recorded, the majority were due to non-medical reasons (1,753 cases), while cancer related factors were reported in 156 cases.

\section{Sum of fresh and frozen/thawed delivery rates (cumulative) \\ This calculation results by dividing the sum of fresh} and FET deliveries by the number of initiated cycles in the same year. The increment in DR after adding FET to fresh deliveries reached $29.06 \%$ (27.93\% in 2013). This increment, however, varied with the age of female partner. In women $\leq 34, \mathrm{DR} / \mathrm{ET}$ increased from $36.14 \%$ to $40.31 \%$; in women $35-39$, from $24.61 \%$ to $28.92 \%$, in women 40 42 years, from $9.52 \%$ to $14.57 \%$; and in women $\geq 43$ years, from $3.85 \%$ to $8.80 \%$ (Figure 3 ).

Overall, during 2014, 18,162 births were registered. Of these, 8,994 were born after IVF/ICSI cycles, while 4,497 were born out of FET, 3,439 after OD and 1,232 after FET OD. Furthermore, 11,373 (62.6\%) babies were born singletons, 6,398 (35.2\%) twins and 391 (2.2\%) were born triplets and more (Table 8 ).

\section{DISCUSSION}

This is the $26^{\text {th }}$ version of the RLA, which has been published continuously since 1990. There are various difficulties when analyzing a regional report consisting of voluntary participation by multiple institutions in several countries. In the absence of an enforceable registration policy, the RLA could be collecting a segment of the national or regional reality. This certainly affects the calculation of number of cycles per country; and also the results will represent a selection of institutions, presumably the best. Only institutions that are certified can report to the RLA, so every country has other centers that do not report because they have not or would not pass a strict accreditation process. Concerning access to ART, there is a sub-registry, which is very difficult to measure. Regional directors of REDLARA are asked to report on the estimated number of centers in each country and the proportion of centers reporting represent 50 to $60 \%$ of the number of institutions that supposedly provide ART treatments. Many of these small institutions exist for few years and then vanish. Nevertheless, the number of cycles reported is estimated 


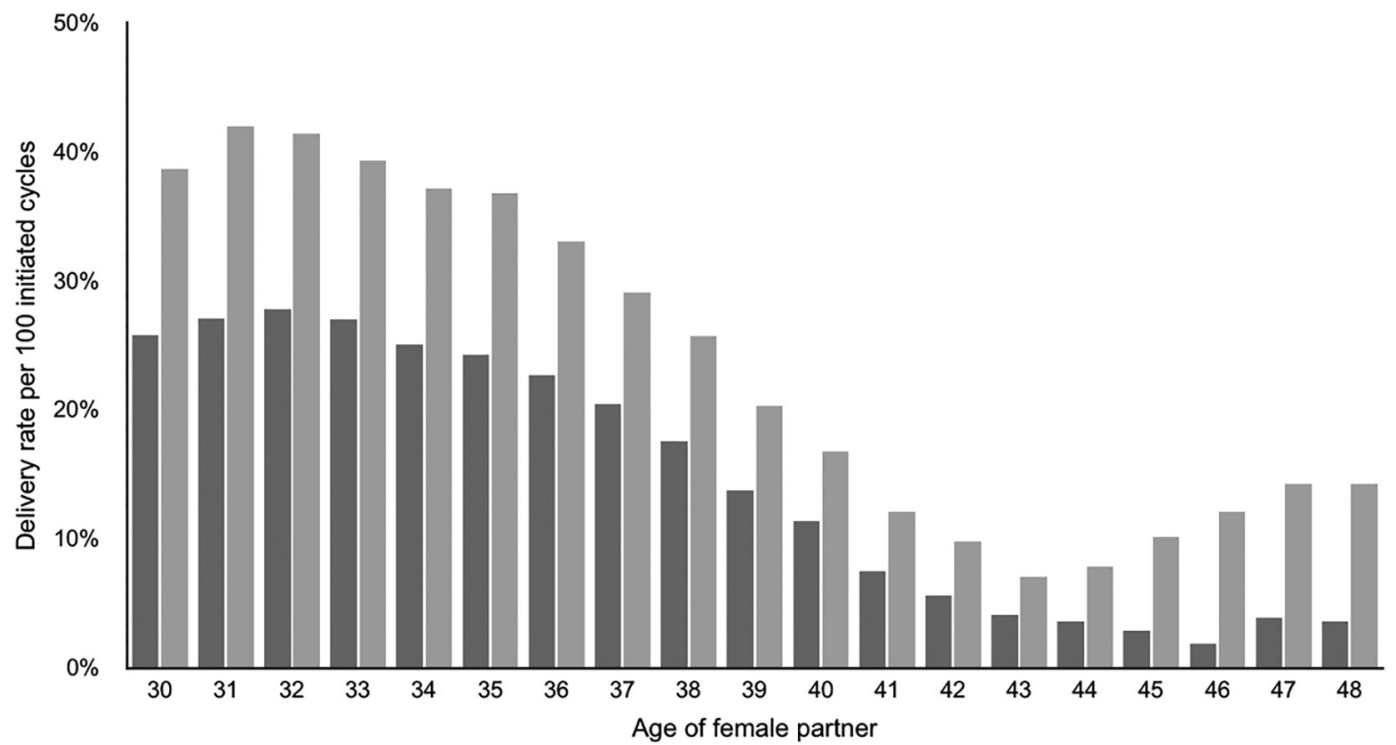

Delivery rate per initiated cycle

Sum of deliveries after FET and IVF/ICSI per initiated cycle

Figure 3. Delivery rate per initiated cycle in IVF/ICSI and cumulative delivery according to the age of female partner, RLA 2014.

to include more than $80 \%$ of treatments provided in the region because the vast majority of well-established and large institutions report to RLA. Therefore, the magnitude of under estimation in availability is thought to be small.

In this version, we found a $16 \%$ rise in the number of initiated cycles compared with the previous report. Nevertheless, access to ART remains very low (116 initiated cycles/million population), compared with 1000 to 2500 cycles per million population found in many European countries (Dyer et al., 2016). It is worth mentioning that Argentina is the first country in Latin America to have a law providing universal access to infertility treatment (Ministerio de Justicia y Derechos Humanos de Argentina, 2013) and correspondingly is the country with the highest number of ART cycles per million population; followed by Chile and Uruguay. Uruguay is the second country with a law recognizing universal access to ART treatment (Poder Legislativo, República Oriental del Uruguay, 2013), we will probably see its impact in access in future report.

Overall, the rise in the number of initiated cycles resulted mostly by an increase in FET and OD cycles. The increase in FET cycles is in part associated with a higher proportion of cycles with total embryo cryopreservation and an increase in the proportion of SET, when compared with 2013 (Zegers-Hochschild et al., 2016;b).

The delivery rate per OPU, after removing all cases with total freezing, for IVF $(27.4 \%)$ and ICSI $(25.05 \%)$ is comparable to $26.9 \%$ delivery rate per OPU for IVF/ICSI published by the US (CDC, 2016); and to $21.9 \%$ and $20.1 \%$ delivery per OPU, in IVF and ICSI, reported by the European Monitoring Consortium EIM (European IVF-Monitoring Consortium (EIM) for the European Society of Human Reproduction and Embryology (ESHRE) et al., 2016). It is not clear however, if the US data and the European data excludes cases with total freezing. In any case, the main issue still is the mean number of embryos transferred which is higher in centres reporting to the RLA than the majority of centres reporting to the EIM.

In general, reproductive efficiency measured as the chance of becoming pregnant after a treatment cycle, is very much influenced by the number of embryos, stage of embryo development at transfer and the health of the woman. Our data show that irrespective of the age of recipient, the transfer of blastocysts generated from healthy donors (OD) produce better outcome than blastocysts generated from similarly young women treated for infertility.

Although the mean number of embryos transferred has diminished over time, in case of IVF/ICSI, from 2.40 in 2010 to 2.06 in 2014, the numbers are still higher than in most western European countries. The proportion of SET and DET has increased, from $13.0 \%$ and $45.2 \%$ in 2010 to $18.25 \%$ and $60.05 \%$ in 2014, respectively (Zegers-Hochschild et al., 2012). Even in the presence of these auspicious improvements, young patients (i.e. under 35 years) with good prognosis treated with IVF/ICSI, and patients undergoing fresh OD, receive three or more embryos in $14.22 \%$ and $22.41 \%$ of ET respectively, which accounts for the high rate of multiple births, especially high order multiples.

As expected, multiple delivery rate was associated with an increase in the risk of perinatal death. Given that the majority of ART procedures are funded by the patient, the current explanation for transferring more embryos is the hope to improve the outcome of any given cycle in its first attempt. Recently, we have shown - using RLA's data, that the transfer of more than two embryos is not associated with a better outcome; on the contrary, it only increases the number of high-order deliveries (Schwarze \& Crosby, 2017). However, the high perinatal mortality is not only associated with multiple births. In the last three years, trends in perinatal mortality have remained high even in singletons. In 2012 and 2013, perinatal mortality rate over 8,331 and 9,987 singleton births was 25.2 per thousand and 29.4 per thousand. It is difficult to interpret whether the drop to 23 per thousand over 11.373 singleton births reported for 2014 reflects better perinatal outcome.

Global perinatal mortality for South America, Central America and the Caribbean can be as high as 19, 22 and 31 per thousand respectively; but the populations are quite different (Organización Panamericana de La Salud, The Partnership for Maternal Newborn and Child Health, Gobierno de Chile Ministerio de Salud, 2008). On the one hand, the majority of 
births in these regions are in younger but less economically resourceful women; on the other hand, women treated with IVF represent a sub selection of older women capable of affording treatment. In autologous IVF/ICSI, $64.7 \%$ of cycles were performed in women $\geq 35$ years and $23.35 \%$ were older than 40 years; so in part, the high perinatal mortality can be partly influenced by an older population. Nevertheless, in general terms, perinatal mortality in births following ART treatments remains higher than in spontaneous pregnancies, and there are reports showing a $70 \%$ increase in perinatal death for IVF singletons compared with spontaneous pregnancies (Helmerhorst et al.,2004).

In the past 10 years, there has been a systematic effort to decrease the number of embryos transferred and thereby the proportion of high order multiple births. In $2004,35.4 \%$ of all births were twins and $11.2 \%$ were triplets and higher. In 2009 the proportion of twins decreased to $33.8 \%$ while triplets and more dropped to $5 \%$ (Zegers-Hochschild et al., 2011); while in 2014, the birth of twins and high order continues to drop to $20.78 \%$ and $0.92 \%$, respectively. Latin America is moving in the right direction and we should pursue in educating both clinicians and patients towards reducing the number of embryos to transfer to a maximum of two embryos, especially in patients with good prognosis.

In conclusion, although we registered an increase in the number of ART cycles every year, access remains low but we expect to see major changes especially in countries such as Argentina and Uruguay with laws providing universal access to ART as part of a reproductive right. It is estimated that many other countries will follow their example, either through laws or other forms of regulation. This facilitated access should be accompanied by a tendency to treat younger women, with a shorter duration of infertility and therefore with higher chances of success when using SET and DET.

\section{CONFLICT OF INTERESTS}

No conflict of interest have been declared.

\section{Corresponding author:}

Fernando Zegers-Hochschild

Oficina del Registro Latino Americano Reproducción

Lo Fontecilla 441, Santiago, Chile.

E-mail: registro@redlara.com

\section{REFERENCES}

Centers for Disease Control and Prevention (CDC), American Society for Reproductive Medicine, Society for Assisted Reproductive Technology. 2014 Assisted Reproductive Technology National Summary Report. Atlanta: US Department of Health and Human Services; 2016

Dyer S, Chambers GM, de Mouzon J, Nygren, KG, Zegers-Hochschild F, Mansour R, Ishihara O, Banker M, Adamson GD. International Committee for Monitoring Assisted Reproductive Technologies world report: Assisted Reproductive Technology 2008, 2009 and 2010. Hum Reprod. 2016;31:1588-609. PMID: 27207175 DOI:10.1093/humrep/dew082

European IVF-Monitoring Consortium (EIM) for the European Society of Human Reproduction and Embryology (ESHRE), Calhaz-Jorge C, de Geyter C, Kupka MS, de Mouzon J, Erb K, Mocanu E, Motrenko T, Scaravelli G, Wyns C, Goossens V. Assisted reproductive technology in Europe, 2012: results generated from European registers by ESHRE. Hum Reprod. 2016;31:1638-52. PMID: 27496943 DOI: $10.1093 /$ humrep/dew151
Helmerhorst FM, Perquin DA, Donker D, Keirse MJ. Perinatal outcome of singletons and twins after assisted conception: a systematic review of controlled studies. BMJ 2004;328:261. PMID: 14742347 DOI: $10.1136 / \mathrm{bmj} .37957 .560278$.EE

Ministerio de Justicia y Derechos Humanos de Argentina. Reproduccion Medicamente Asistida Ley 26.862. Acceso integral a los procedimientos y técnicas médicoasistenciales de reproducción médicamente asistida. 2013. Available at: http://servicios.infoleg.gob.ar/ infolegInternet/anexos/215000-219999/216700/norma. htm. Accessed: 10/7/2017.

Organización Panamericana de La Salud, The Partnership for Maternal Newborn and child Health, Gobierno de Chile Ministerio de Salud. Mortalidad Materna y Neonatal en ALC y estrategias de reducción. 2008. Available at: www.who. int/pmnch/activities/sintesis_situacionmortalidad_en_alc. pdf. Accessed: 10/7/2017.

Poder Legislativo, República Oriental del Uruguay. Ley No 19.167. Técnicas de Reproducción Humana Asistida. 2013. Available at: https://parlamento.gub.uy/ documentosyleyes/leyes/ley/19167. Accessed: 10/7/2017.

Schwarze JE, Crosby JA. Transfer of more than two embryos, regardless of the age of the female partner, is not beneficial for neither the mothers nor the babies: lessons from the Latin American Registry of Assisted Reproductive Techniques. JBRA Assist Reprod. 2017;21:19-22. PMID: 28333027 DOI: $10.5935 / 1518-0557.20170006$

Zegers-Hochschild F, Adamson GD, de Mouzon J, Ishihara O, Mansour R, Nygren K, Sullivan E, van der Poel S; International Committee for Monitoring Assisted Reproductive Technology; World Health Organization. The International Committee for Monitoring Assisted Reproductive Technology (ICMART) and the World Health Organization (WHO) Revised Glossary on ART Terminology, 2009. Hum Reprod. 2009;24:2683-7. PMID: 19801627 DOI: $10.1093 /$ humrep/dep343

Zegers-Hochschild F, Schwarze JE, Crosby JA, de Souza MCB. Twenty years of assisted reproductive technology (ART) in Latin America. JBRA Assist Reprod. 2011;15:1930.

Zegers-Hochschild F, Schwarze JE, Crosby J, Musri C, de Souza MCB. Assisted reproductive technologies in Latin America: The Latin American Registry, 2010. JBRA Assist Reprod. 2012;16:320-8.

Zegers-Hochschild F, Schwarze JE, Crosby JA, Musri C, Urbina MT; Latin American Network of Assisted Reproduction (REDLARA). Assisted reproductive techniques in Latin America: the Latin American Registry, 2013. Reprod Biomed Online. 2016a;32:61425. PMID: 26997476 DOI: 10.1016/j.rbmo.2016.02.012

Zegers-Hochschild F, Schwarze JE, Crosby JA, Musri C, Urbina MT; Latin American Network of Assisted Reproduction (REDLARA). Assisted reproductive techniques in Latin America: the Latin American Registry, 2013. JBRA Assist Reprod. 2016b;20:49-58. PMID: 27244761 DOI: 10.5935/1518-0557.20160013 
Supplementary Table 1. Centres reporting to Latin America Registry of ART in 2014 ARGENTINA

- Instituto de Fertilidad Asistida

- Centro de Estudios en Ginecología y Reproducción (CEGYR)

- Centro de Salud Reproductiva (CER)

- Instituto Tersoglio

- Centro Integral de Ginecología, Obstetricia y Reproducción (CIGOR)

- Centro de Investigaciones en Medicina Reproductiva (CIMER)

- Centro de Medicina Reproductiva Bariloche

- Centro de Estudios en Reproducción y Procedimientos de Fertilización Asistida (CRECER)

- FECUNDITAS

- FERTILAB

- gestar

- Hospital de Clínicas

- FECUNDART

- Instituto de Medicina Reproductiva

- Mater, Medicina Reproductiva

- Nascentis, Medicina Reproductiva

- HALITUS, Instituto Médico

- Instituto Medico de ginecología y Fertilidad PREFER

- PREgNA, Medicina Reproductiva

- Programa de asistencia reproductiva PROAR

- PROCREARTE

- Fertilidad San Isidro

- SEREMAS

- VITAE, Medicina Reproductiva

BOLIVIA

- CENALFES

- Instituto de Salud Reproductiva

- EMBRIOVID, centro integral de reproducción y especialidades médicas

BRAZIL

- ANDROLAB, Clinica e Laboratório de Reprodução Humana e Andrologia

- ANDROFERT, Centro de Referencia em Reprodução Masculina

- FERTIVITRO, Centro de Reprodução Humana

- BIOS, Centro de Medicina Reprodutiva

- Centro de Reprodução Humana de Campinas

- Centro de Medicina Reprodutiva

- VIDA, Centro de Fertilidade REDE D'OR

- Clinica FERTWAY

- NASCER, Medicina Reprodutiva Ltda.

- ORIGINARE, Centro de Investigação e Reprodução Humana

- CLINIFERT, Centro de Reprodução Humana

- CONCEPTUS, Centro de Reprodução Assistida de Cear

- CONCEBER, Centro de Medicina Reprodutiva

- Clinica ORIGEN

- Clinica Pro-Genesis

- Centro de Reprodução Humana MONTELEONE

- Fértile Diagnósticos 
- CEERH, Centro Especializado em Reprodução Humana

- EMBRYOLIFE, Instituto de Medicina Reprodutiva

- Centro de Reprodução Humana, Endoscopia e Medicina Fetal de Bahia (CENAFERT)

- Instituto VERHUM

- Clinica FERTIBABY BH

- FECUNDA, Reprodução Humana

- FELICCITA, Instituto de Fertilidade Ltda.

- HUMANA, Medicina Reprodutiva (Ex Centro de Reprodução Assistida FEMINA)

- FERTILITY, Centro de Fertilização Assistida de Campo Grande

- FERTILITY, Centro de Fertilização Assistida

- FERTIL Reprodução Humana

- REPROFERTY

- FERTICLIN, Clínica de Fertilidade Humana

- GENESIS, Centro de Assistência em Reprodução Humana

- Clinica Genics, Medicina Reprodutiva e Genômica

- FERTIPRAXIS, Centro de Reprodução Humana (Ex Fert. Gin. e Obst. de Barra)

- GERA, Grupo de endoscopia e Reprodução Assistida

- Instituto de Saúde Da Mulher, Cegonha Medicina Reprodutiva

- IVI São Paulo, Chedid Grieco S.A.

- HUMANA (PRIMORDIA, Medicina Reprodutiva Huntington RJ)

- Hospital de Clínicas de Ribeirão Preto

- HUNTINGTON, Centro de Medicina Reprodutiva

- JULES WHITE, Centro de Medicina Reprodutiva

- IMR, Instituto de Medicina Reprodutiva e Fetal

- Serviço de Reprodução Humana Del Hospital e Maternidade Santa Joana

- Life Reprodução humana

- FERTILITAT, Centro de Medicina Reprodutiva

- Clínica MATRIX

- Pro-criar Monte Sinaí

- Centro de Reprodução Humana Nilo Frantz

- Clinica ORIGEN

- Clinica PRO-CRIAR, Medicina Reprodutiva

- Clinica PRO NASCER

- Centro de Reprodução Humana De San Jose de Rio Preto

- GENESIS, Centro de Reprodução Humana

- Centro de Reprodução Humana Prof. Franco Junior

- Centro de Ensino e Pesquisa em Reprodução Assistida (Centro de Rep. Assist. Hospital Da ASA SUL)

\section{CHILE}

- UMR Clínica de la Mujer Antofagasta

- Centro de Estudios Reproductivos (CER)

- Unidad de Medicina Reproductiva, Clínica Alemana

- Unidad de Medicina Reproductiva, Clínica las Condes

- Unidad de Medicina Reproductiva, Clínica de la Mujer

- IVI Santiago de Chile

- Programa e Fertilización Asistida I.D.I.M.I.

- Clínica Monteblanco 
- Centro de Fertilidad y Medicina Reproductiva Concepción S.A.

COLOMBIA

- Centro FECUNDAR, Cali

- Unidad de fertilidad del Coutry Itda. CONCEPTUM

- Asociados en Fertilidad y Reproducción Humana

- FERTIVIDA

- Centro Médico IMBANACO

- Instituto de Fertilidad Humana S.A.S. (INSER)

- IN SER, Instituto Antioqueño de Reproducción

- Clinica Machicado SAS

- PROCREAR

- Unidad de Fertilidad, Procreación Medicamente Asistida

- Union temporal IN SER eje cafetero

\section{ECUADOR}

- Clínica de Medicina Reproductiva BIOGEPA

- Centro Ecuatoriano de Reproducción Humana

- Clínica INFES

- Instituto Nacional de Investigación de Fertilidad y Esterilidad (INNAIFEST)

- CONCEBIR, Unidad de Fertilidad y Esterilidad

- Unidad de Fertilidad Hospital Alcívar

GUATEMALA

- Centro de Reproducción Humana S.A. (CER)

MEXICO

- Biofertility Center

- Biología de la Reproducción Humana, Cirugía Reproductiva Gin. y Obst. (INSEMER)

- Centro de Diagnóstico Ginecológico

- CEMAIN

- Clínica de Biología de la Reproducción

- Centro médico nacional 20 de Noviembre del ISSSTE

- Instituto para el estudio de la Concepción Humana IECH

- Centro de Reproducción Asistida del Hospital Español (HISPAREP)

- Centro de Reproducción Asistida del Occidente

- Centro de Reproducción Asistida de Saltillo

- Centro Universitario de Medicina Reproductiva

- CREASIS SC

- emBRyos POLANCO SA de CV

- Fertility Center Cancún

- Ginecología y Reproducción Asistida GYRA

- Instituto para el estudio de la concepción humana de Baja California

- Instituto Mexicano de Alta Tecnología Reproductiva S.C. (INMATER)

- Instituto IMER de Tijuana

- Instituto Mexicano de infertilidad

- Instituto Médico de la mujer (RED CREA)

- Instituto de Ciencias en Reproducción Humana, sede Guadalajara

- Instituto de Ciencias en Reproducción Humana, sede Matamoros

- Centro especializado para la atención de la mujer (CEPAM) 
- INGENES

- INGENES Guadalajara

- Instituto de Ciencias en Reproducción Humana (VIDA), sede León

- Instituto de ciencias en reproducción humana del Sureste (Vida Merida)

- Centro de Medicina Reproductiva FILIUS

- PROGEN, Reproducción asistida y medicina fetal

- Centro especializado en esterilidad y Reproducción Humana (CEERH)

- Instituto de Ciencias en reproducción humana VIDA, ciudad de Mexico.

NICARAGUA

- Centro de Fertilidad de Nicaragua

\section{PANAMA}

- IVI Panamá S.A.

\section{PARAGUAY}

- Neolife, Medicina y cirugía reproductiva

\section{PERU}

- Clínica CEFRA, Centro de Fertilidad y Reproducción Asistida

- CERFEGIN

- Centro de Fertilidad y Ginecología del Sur (CFGS)

- FERTILAB, Laboratorio de Reproducción asistida

- Clínica Miraflores, Instituto de Ginecología y Fertilidad

- Grupo Pranor, Clínica CONCEBIR

- Grupo Pranor, Instituto de Ginecología y Reproducción

\section{DOMINICAN REPUBLIC}

- Instituto de Reproducción y Ginecología del CIBAO (IREGCI)

\section{URUGUAY}

- Centro de Esterilidad Montevideo (CEM)

- Centro de Reproducción Humana del Interior

VENEZUELA

- FERTILAB

- UNIFERTES

- Centro Medico docente la Trinidad

- EMBRIOS, Centro de Fertilidad y Reproducción Humana, Hospital de Clínicas de Caracas

- GENESIS, Unidad de Fertilidad y Reproducción

- Instituto Venezolano de Fertilidad

- Laboratorios In Vitro de Venezuela 